\title{
Penentuan Umur Bercak Darah Manusia pada Kain Katun dengan Menggunakan High Performance Liquid Chromatography
}

\author{
Mohammad Tegar Indrayana ${ }^{1}$,Wibisana Widiatmaka ${ }^{2}$, Ade Firmansyah Sugiharto ${ }^{2}$, Ridla Bakri ${ }^{3}$
}

\begin{abstract}
:
This research is to study the method in determining the age of human bloodstain due the rarity of human bloodstain researches in Indonesia, by analyzing the $\mathrm{X}$ and $\mathrm{Y}$ peaks that appeared in High Performance Liquid Chromatography (HPLC). This research is experimental with time series for 11 days observation by exposing the bloodstain onto 33 pieces of cotton fabric, each measuring $1 \mathrm{~cm} \mathrm{x} 1 \mathrm{~cm}$ that originated from 3 respondents with environmental conditions of the FKUI/RSUPN Dr. Cipto Mangunkusumo Forensic and Medico-legal Department which represents the area of Central Jakarta. The results of this research is the $\mathrm{X}$ and $\mathrm{Y}$ peaks do not point to a linearity so that the criteria for linear regression equation is not met. The conclusion of this research is age of human bloodstain on cotton fabric by analyzing X peak with HPLC cannot yet be used pragmatically in the field in accord to the conditions at the crime scene.
\end{abstract}

Keywords:Determining the age of human bloodstain, $X$ and Y peaks, HPLC, cotton fabric

\section{PENDAHULUAN}

Bercak darah merupakan elemen barang bukti yang penting di tempat kejadian perkara (TKP) merupakan barang bukti yang sangat penting. Selain dipergunakan untuk pemeriksaan DNA dan melakukan rekonstruksi kejadian, bercak darah di TKP dapat dipergunakan untuk memperkiraan umur bercak darah yang bermanfaat untuk membuat rentang waktu (time frame) kejadian terjadinya suatu peristiwa pidana.

Di Indonesia, kewenangan pencarian dan pengumpulan barang bukti di TKP menjadi kewenangan Kepolisian Republik Indonesia sesuai Undang-undang No.2 Tahun 2002 tentang Kepolisian Negara Republik Indonesia, pasal 15

Bagian Ilmu Kedokteran Forensik dan Medikolegal, Fakultas Kedokteran, Universitas Riau, Pekanbaru, Indonesia

2 Departemen Forensik dan Medikolegal, Fakultas Kedokteran Universitas Indonesia, Jakarta, Indonesia

3 Departemen Kimia, Fakultas Matematika dan Ilmu Pengetahuan Alam, Universitas Indonesia, Depok, Indonesia ayat 1.Namun kehadiran dokter forensik di TKP sewaktu-waktu dapat diperlukan tergantung dari pertimbangan penyidik.

Penelitian mengenai memperkirakan umur bercak darah manusia telah banyak dilakukan oleh beberapa peneliti di dunia. Mereka meneliti berbagai macam komponen yang ada di dalam darah yang kemudian dikuantifikasi dengan mempergunakan berbagai macam teknik diantaranya adalah High Performance Liquid Chromatography (HPLC), Diffuse Reflectance Spectroscopy (DRS), Electrone Paragmetic Resonance (EPR), immunoelektrofosis hingga meneliti degradasi Ribo Nucleic Acid (RNA) pada darah. ${ }^{1-7}$ Namun penelitian tersebut dilakukan pada iklim dan kondisi lingkungan yang berbeda dengan iklim di Indonesia sehingga untuk pemanfaatan secara pragmatis belum dapat diaplikasikan mengingat komponen bercak darah sangat rentan terhadap perubahan lingkungan terutama suhu dan kelembaban udara. 
Penelitian ini dilakukan untuk mengidentifikasi dan mengkuantifikasi partikel ataupun zat pada bercak darah yakni produk degradasi dari heme berupa peak $\mathrm{X}$ dan $\mathrm{Y}$ dengan mempergunakan High Performance liquid Chromatography (HPLC)untuk melihat hubungan (korelasi) antara jumlah produk degradasi heme (peak X dan Y) pada bercak darah dengan bertambahnya umur bercak darah manusia sesuai kondisi lingkungan yang ada di wilayah Jakarta Pusat. Tujuannya akhirnya untuk melihat apakah penentuan umur bercak darah manusia dengan mempergunakan HPLC dapat dipergunakan secara pragmatis sesuai kondisi TKP di Indonesia.

\section{METODE}

Penelitian merupakan penelitian eksperimental dengan time seriesyang dilakukan pada tanggal 12 s/d 23 Desember 2012 di lingkungan Departemen Forensik dan Medikolegal, Fakultas Kedokteran Universitas Indonesia - Rumah Sakit Umum Pusat Dr. Cipto Mangunkusumo, sedangkan analisis dengan HPLC dilakukan di laboratorium Departemen Kimia, Fakultas Matematika dan Ilmu Pengetahuan Alam Universitas Indonesia.

Sampel pada penelitian ini adalah kain katun berwarna putih yang direndam dalam darah manusia dan dikeringkan pada udara terbuka selama rentang waktu 1-11 hari.Besar sampel untuk penelitian ini berdasarkan rumus untuk analisis multivariat regresi linear, ${ }^{8}$ adalah sebanyak 33 sampel.Sedangkan datadata mengenai suhu dan kelembaban udara rata-rata per hari diperoleh dari Badan Meteorologi Klimatologi dan Geofisika (BMKG) Kemayoran.

Kain katun yang memenuhi persyaratan inklusi adalah kain katun yang berwarna putih dan telah direndam dengan darah yang berasal dari subyek manusia dengan kadar $\mathrm{Hb}$ pada laki-laki diatas 13.5 $\mathrm{gr} / \mathrm{dl}$ atau perempuan diatas $12 \mathrm{gr} / \mathrm{dl}{ }^{9}$

Data akan diolah secara deskriptif dan analitik mengunakan program SPSS version 17.0 for
Windows. Data yang diolah secara deskriptif adalah karakteristik dari subjek donor berupa jenis kelamin, umur, dan kadar $\mathrm{Hb}$ serta data-data sampel bercak darah yang terdiri dari hari pengambilan, jam pengambilan sampel, jam melakukan analisis dengan HPLC, suhu, kelembaban udara, hasil analisis HPLC (berupa peak $\mathrm{X}$ dan peak $\mathrm{Y}$ ), retensi waktu (untuk peak X dan peak Y).

Setelah data yang ada dideskripsikan, dilakukan analisis korelatif bivariat dari masingmasing variabel bebas, yaitu peak $\mathrm{X}$ dan peak $\mathrm{Y}$ (skala numerik), terhadap variabel tergantung, yaitu usia bercak darah (skala numerik), dengan menggunakan uji korelasi Pearson. Dari uji tersebut didapatkan kekuatan korelasi (r), nilai kemaknaan (p), dan arah korelasi dari masing-masing variabel. ${ }^{10}$

Selanjutnya dilakukan seleksi variabel bebas untuk dimasukkan dalam analisis multivariat berdasarkan nilai p. Lalu dilakukan analisis multivariat dengan metode regresi linear untuk menilai korelasi antara variabel bebas dengan variabel tergantung sehingga diperoleh suatu rumus regresi linear. Kualitas rumus yang diperoleh dinilai kemampuan diskriminasinya dengan melihat nilai $\mathrm{R}^{2}$ dan kemampuan kalibrasinya dengan melihat hasil uji ANOVA. ${ }^{10}$

\section{HASIL}

Penelitian perkiraan umur bercak darah pada kain katun yang diamati selama 11 hari yaitu dari 12 s/d 23 Desember 2012 ini diambil sebanyak 33 kain katun yang masing-masing mewakili 3 responden yang diberi kode A, B dan C. Responden A adalah laki-laki berusia 20 tahun dengan kadar $\mathrm{Hb} 12,5 \mathrm{gr} / \mathrm{dl}$. Responden $\mathrm{B}$ adalah perempuan berusia 21 tahun dengan kadar $\mathrm{Hb} 11,3 \mathrm{gr} / \mathrm{dl}$. Responden $\mathrm{C}$ adalah laki-laki berusia 28 tahun dengan kadar $\mathrm{Hb} 13 \mathrm{gr} / \mathrm{dl}$. 
JIK, Jilid 8, Nomor 1, Maret 2014, Hal. 8-17

Tabel 1. Analisis Peak X dan Peak Y dengan HPLC

\begin{tabular}{|c|c|c|c|c|c|c|c|c|c|}
\hline \multirow[t]{2}{*}{ Harike } & \multirow[t]{2}{*}{ Ho Sampel } & \multirow{2}{*}{$\begin{array}{c}\text { Jam } \\
\text { Pengamhlan } \\
\text { sampel }\end{array}$} & \multirow{2}{*}{$\begin{array}{c}\text { Jam } \\
\text { Analicis } \\
\text { Sampel } \\
\text { pada } \\
\text { HPLC }\end{array}$} & \multirow[t]{2}{*}{ Sthe (p) } & \multirow[t]{2}{*}{$\begin{array}{c}\text { Kelembaban } \\
\text { (\%) }\end{array}$} & \multicolumn{2}{|c|}{$\begin{array}{c}\text { Hasil Analisis HPLC } \\
\text { (mat) }\end{array}$} & \multicolumn{2}{|c|}{$\begin{array}{l}\text { Retensi Wakhu } \\
\text { (meii) }\end{array}$} \\
\hline & & & & & & Peak X & Peak Y & Peak X & Peak Y \\
\hline \multirow[t]{3}{*}{$\mathbf{1}$} & $1 \mathbf{A}$ & $07.45 \mathrm{WIB}$ & $0930 \mathrm{WIB}$ & 28.0 & 80 & A) 44066 & A) 50870 & A) 69 & A) 6,9 \\
\hline & $1 \mathrm{~B}$ & & & & & B) 59938 & B) 19938 & B) 7,6 & B) 61 \\
\hline & l.c & & & & & c) 27807 & c) 17515 & c) 61 & c) 6,2 \\
\hline \multirow[t]{3}{*}{2} & $2 \mathrm{~A}$ & $08.30 \mathrm{WIB}$ & $15.00 \mathrm{WIB}$ & 28.2 & 80 & A) 51366 & A) 33286 & A) 62 & A) 6,8 \\
\hline & $2 \mathrm{~B}$ & & & & & B) 177520 & B) 30499 & B) 6,2 & B) 6,7 \\
\hline & $2 . c$ & & & & & C) 43467 & C) 24833 & c) 62 & c) 6,8 \\
\hline \multirow[t]{3}{*}{3} & $3 \mathbf{A}$ & $15.15 \mathrm{WIB}$ & $1610 \mathrm{WIB}$ & 26.6 & 88 & A) 5949 & A) 30536 & A) 6,6 & A) 7,2 \\
\hline & $3 \mathbf{B}$ & & & & & B) 160583 & B) 24813 & B) 6,5 & B) 7,0 \\
\hline & $3 . c$ & & & & & c) 49466 & c) 27406 & c) 65 & c) 7,0 \\
\hline \multirow[t]{3}{*}{4} & $4 \mathrm{~A}$ & $13.30 \mathrm{WIB}$ & $1430 \mathrm{WIB}$ & 29.7 & 71 & A) 76867 & A) 29802 & A) 7,0 & A) 7,6 \\
\hline & $4 B$ & & & & & В) 131439 & B) 26834 & B) 7,8 & B) 82 \\
\hline & $4 . \mathrm{C}$ & & & & & C) 7585 & c) 25591 & c) 78 & c) 8,3 \\
\hline \multirow[t]{3}{*}{5} & $5 \mathrm{~A}$ & $09.10 \mathrm{WIB}$ & $1010 \mathrm{WIB}$ & 28.6 & 76 & A) 46398 & A) 24094 & A) 59 & A) 5,7 \\
\hline & $5 \mathrm{~B}$ & & & & & B) 269429 & B) 27350 & B) 6,0 & B) 65 \\
\hline & $5 . c$ & & & & & c) 64746 & c) 31195 & c) 61 & c) 6,6 \\
\hline \multirow[t]{3}{*}{6} & $6 \mathrm{~A}$ & $08.30 \mathrm{WIB}$ & $1010 \mathrm{WIB}$ & 27.8 & 80 & A) 55741 & A) 34997 & A) 6,1 & A) 6,6 \\
\hline & $6 \mathrm{~B}$ & & & & & B) 66402 & B) 35751 & B) 6,6 & B) 72 \\
\hline & $6 . \mathrm{c}$ & & & & & C) 41647 & C) 24892 & c) 64 & c) 6,7 \\
\hline \multirow[t]{3}{*}{7} & $7 \mathrm{~A}$ & $11.10 \mathrm{WIB}$ & $1515 \mathrm{WIB}$ & 27.6 & 81 & A) 70936 & A) 30726 & A) 6,4 & A) 6,9 \\
\hline & $7 \mathrm{~B}$ & & & & & B) 130440 & B) 39625 & B) 6,5 & B) 71 \\
\hline & $7 . c$ & & & & & c) 101936 & c) 30645 & c) 6,4 & c) 6,9 \\
\hline \multirow[t]{3}{*}{8} & $8 \mathrm{~A}$ & $08.50 \mathrm{WIB}$ & $10.00 \mathrm{WLB}$ & 30.3 & 68 & A) 50001 & A) 20885 & A) 5,8 & A) 6,3 \\
\hline & $8 \mathrm{~B}$ & & & & & B) 75851 & В) 29192 & B) 6,3 & B) 6.8 \\
\hline & $8 . c$ & & & & & c) 111308 & c) 24100 & c) 5,8 & c) 6,3 \\
\hline \multirow[t]{3}{*}{9} & $9 \mathrm{~A}$ & $10.00 \mathrm{WIB}$ & $13.00 \mathrm{WIB}$ & 28.2 & 76 & A) 65211 & A) 30020 & A) 6,4 & A) 6,9 \\
\hline & $9 \mathbf{B}$ & & & & & B) 73517 & B) 34393 & B) 6,1 & B) 6,6 \\
\hline & 9.c & & & & & c) 6845 & c) 40488 & c) 6.8 & c) 7,3 \\
\hline \multirow[t]{3}{*}{10} & $10 \mathrm{~A}$ & $12.00 \mathrm{WIB}$ & $13.45 \mathrm{WIB}$ & 27.0 & 83 & A) 5124 & A) 39695 & A) 73 & A) 7,8 \\
\hline & $10 \mathrm{~B}$ & & & & & В) 25182 & B) 11784 & B) 7,4 & B) 79 \\
\hline & $10 . c$ & & & & & c) 54336 & c) 2585 & c) 6,6 & c) 7,6 \\
\hline \multirow[t]{3}{*}{11} & $11 \mathrm{~A}$ & $12.15 \mathrm{WIB}$ & $1410 \mathrm{WIB}$ & 26.4 & 87 & A) 59681 & A) 2162 & A) 119 & A) 11,9 \\
\hline & $11 \mathrm{~B}$ & & & & & B) 95747 & B) 7064 & B) 17,6 & B) 17,6 \\
\hline & 11.c & & & & & c) 27521 & c) 1960 & c) 115 & C) 10,3 \\
\hline
\end{tabular}



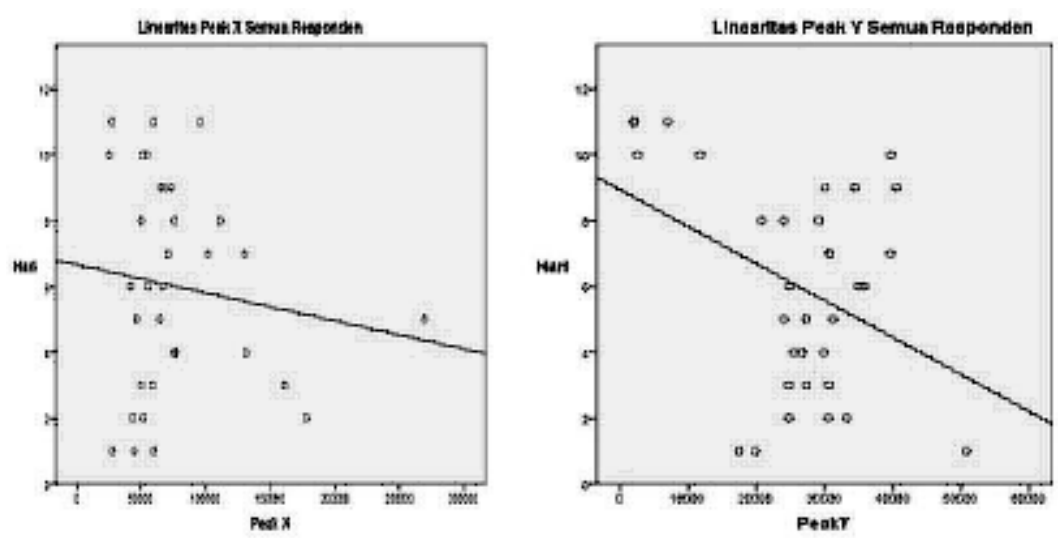

Gambar1.Linearitas Peak X dan Peak Y

Gambar1 menggambarkan linearitas peak X dan peak Y selama 11 hari pengamatan. Terlihat peak X dan peak Y menyebar secara acak dan tidak berada dalam suatu kesegarisan (linearitas).
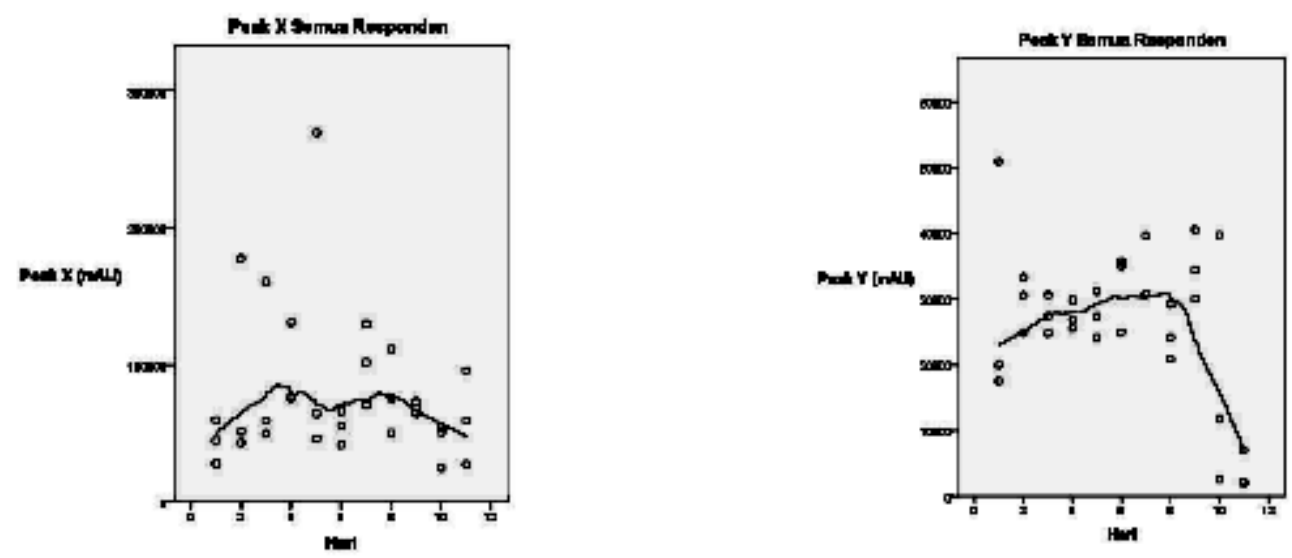

Gambar2.Peak X dan Ypada semua responden dari hari 1 - 11

Pada gambar2, terlihat bahwa peak $\mathrm{X}$ untuk seluruh responden memang mengalami peningkatan pada hari $1 \mathrm{~s} / \mathrm{d} 3$, namun pada hari $4 \mathrm{~s} / \mathrm{d} 6$ mengalami penurunan. Kemudian pada hari 7 s/d 8 mengalami peningkatan kembali dan pada hari ke 9 s/d 11 mengalami penurunan. Sehingga gambaran yang tampak seolah-olah menyerupai double peaks. Sedangkan untuk peak $\mathrm{Y}$ untuk seluruh responden, mengalami peningkatan pada hari $1 \mathrm{~s} / \mathrm{d} 8$ dan setelah itu terjadi penurunan peak yang cukup drastis.
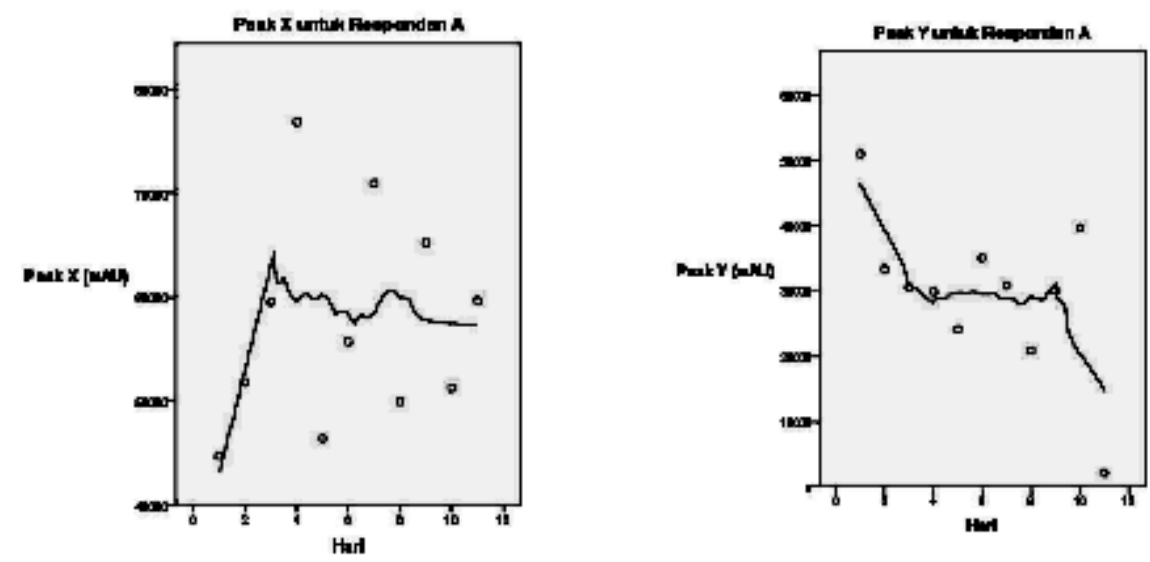

Gambar 3.Peak X dan Ypada responden A dari hari 1-11 
Grafik diatas menunjukkan gambaran peak X pada responden A. Terlihat pada gambar 3, bahwa dari hari $1 \mathrm{~s} / \mathrm{d} 3$ peak $\mathrm{X}$ mengalami kenaikan yang cukup tajam.Pada hari ke 4 s/8 tampak peak X mengalami kenaikan dan penurunan yang cukup fluktuatif.Lalu pada hari ke 9 s/d 11 peak X cenderung mengalami stagnasi.Gambaran peak $\mathrm{Y}$ untuk responden A terlihat pada hari $1 \mathrm{~s} / \mathrm{d} 3$ peak $\mathrm{Y}$ mengalami penurunan yang cukup tajam. Lalu di hari 4 s/d 9 peak $\mathrm{Y}$ mengalami fluktuatif namun dengan pola yang cenderung mendatar dan di hari $10 \mathrm{~s} / \mathrm{d} 11$ peak $\mathrm{Y}$ kembali mengalami penurunan yang cukup drastis.

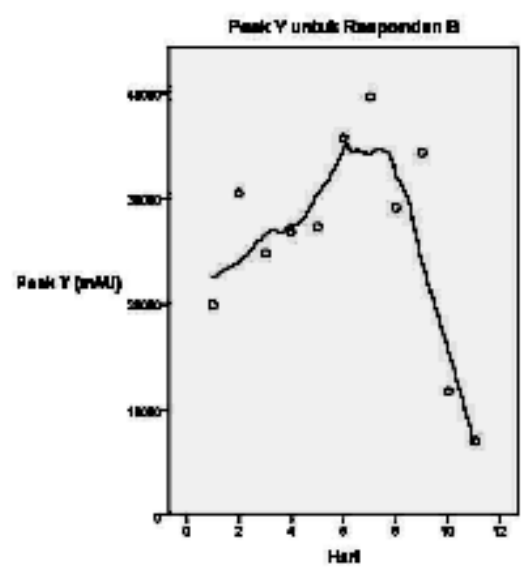

Gambar 4.Peak X dan Y pada responden B dari hari 1-11

Gambar 4 adalah gambaran peak X dan Y pada responden B. Peak X pada responden ini gambarannya menyerupai pelana kuda.Terlihat pada hari 1 s/d 3 peak mengalami kenaikan yang cukup tajam, lalu hari ke 4 menuju hari ke 5 mengalami penurunan yang cukup tajam dan meningkat kembali pada hari ke 6, setelah itu pada hari ke 7 s/d 11 cenderung mengalami penurunan.Pada responden ini tampak peak $\mathrm{Y}$ memiliki kecenderungan meningkat pada hari $1 \mathrm{~s} / \mathrm{d} 6$, dan menuju hari ke 7 cenderung mendatar.Setelah itu pada hari ke $8 \mathrm{~s} / \mathrm{d}$ 11 , peak $\mathrm{Y}$ mengalami penurunan yang tajam.
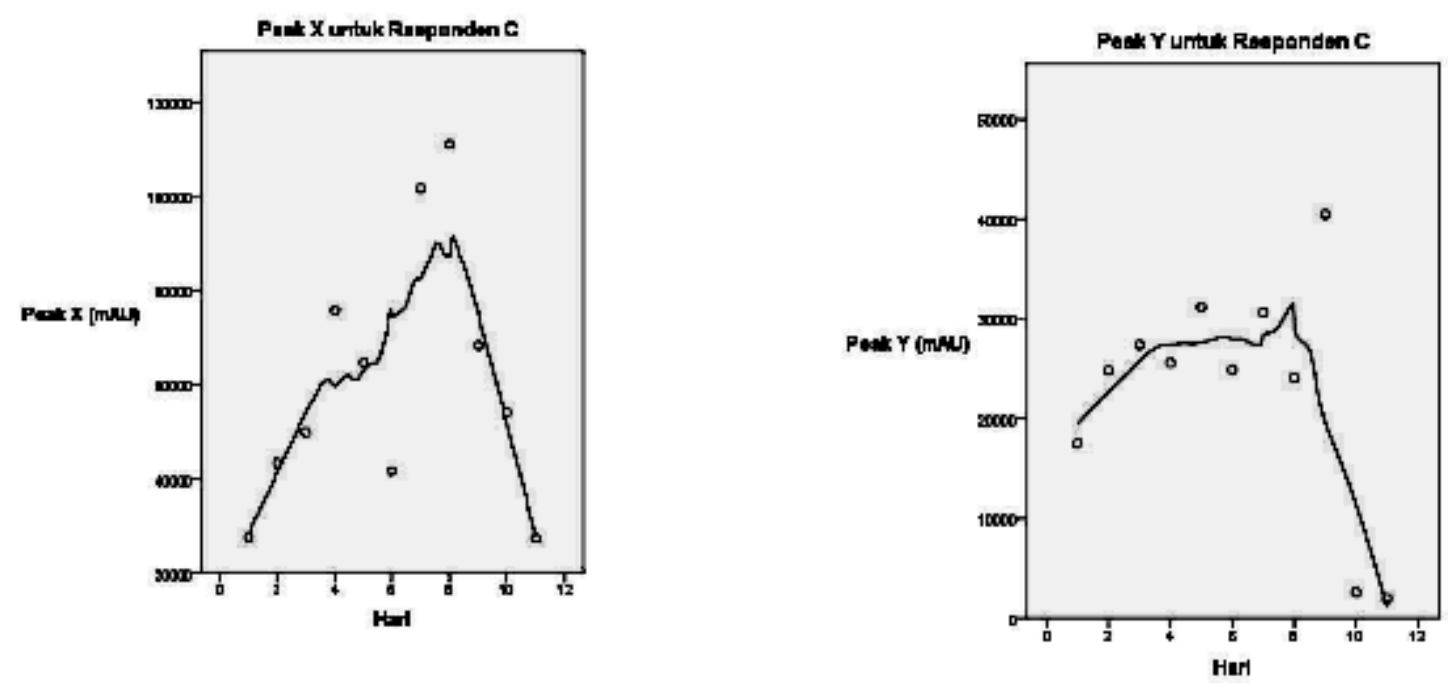

Gambar 5.Peak X dan Y pada responden C dari hari 1-11 
Gambar 5 adalah gambaran peak X dan Y pada responden $\mathrm{C}$. Pada grafik ini peak $\mathrm{X}$ mengalami peningkatan yang cukup signifikan mulai dari hari $1 \mathrm{~s} / \mathrm{d}$ 8. Melewati hari ke 8, peak X mengalami penurunan yang sangat drastis.Gambaran peak $\mathrm{Y}$ untuk responden $\mathrm{C}$, terlihat pada grafik diatas dari hari $1 \mathrm{~s} / \mathrm{d} 8$ peak mengalami kecenderungan untuk meningkat lalu pada hari ke $9 \mathrm{~s} / \mathrm{d} 11$ pengalami penurunan yang drastis.
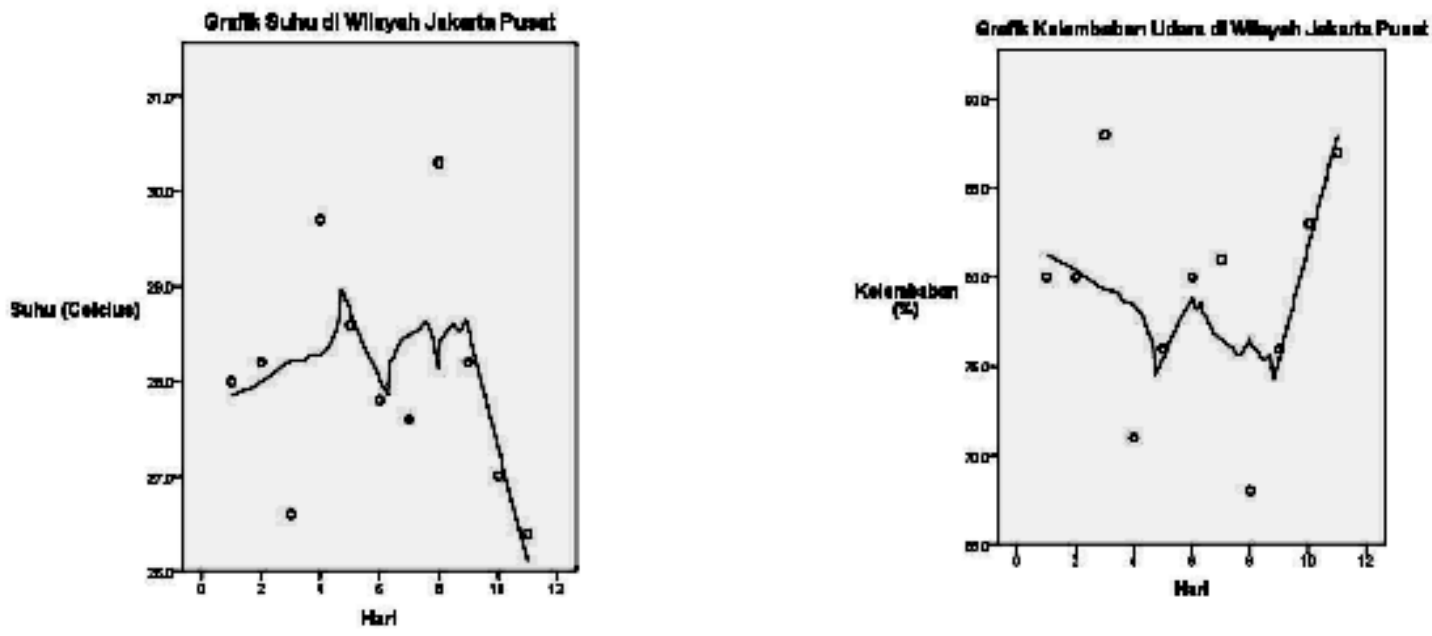

Gambar 6. Perubahan suhu dan kelembaban udara pada hari 1 s/d 11 penelitian

Gambar 6 diatas menunjukkan perubahan suhu dan kelembaban udara rata-rata di wilayah Jakarta Pusat selama waktu penelitian. Terlihat bahwa pada hari $1 \mathrm{~s} / \mathrm{d} 8$ terlihat perubahan suhu yang berfluktuatif, namun pada hari 9 s/d 11 suhu udara mengalami penurunan yang drastis. Sedangkan perubahan kelembaban udara rata-rata di wilayah Jakarta Pusat, terlihat grafik mengalami perubahan fluktuatif dari hari ke $1 \mathrm{~s} / \mathrm{d} 8$, namun pada hari ke 9 s/d 11 grafik kelembaban udara rata-rata mengalami peningkatan yang tajam.

\section{DISKUSI}

Penelitian ini dilakukan untuk menjawab pertanyaan penelitian yaitu bagaimana hubungan (korelasi) antara jumlah produk degradasi heme (peak X dan Y) pada bercak darah dengan bertambahnya umur bercak darah manusia yang dianalisis dengan alat HPLC sesuai kondisi lingkungan yang ada di wilayah Jakarta Pusat.Tujuan diadakannya penelitian ini adalah untuk mengetahui apakah hasil pemeriksaan bercak darah dengan HPLC dapat digunakan untuk memperkirakan umur bercak darah manusia dengan kondisi lingkungan yang ada di wilayah Jakarta Pusat.
Secara statistik untuk menentukan adanya korelasi antara variabel dependen dan variabel independen dengan skala numerik dipergunakan uji korelasi Pearson apabila distribusinya normal atau uji korelasi Spearman jika distribusinya tidak normal, yang tujuannya agar dapat dilakukan uji analisis multivariat sehingga diperoleh persamaan regresi linear. ${ }^{20}$ Penelitian ini juga ingin mengetahui hubungan satu variabel terikat dengan skala pengukuran numerik (umur bercak dalam hari) dengan satu atau lebih variabel bebas berskala numerik (peak $\mathrm{X}$ dan peak $\mathrm{Y}$ ). Sehingga data-data yang diperoleh harus terlebih dahulu diuji untuk melihat apakah syarat-syarat regresi linear terpenuhi. Syarat-syarat regresi linear meliputi linearitas, sebaran residu harus terdistribusi secara normal, rerata residu nol, tidak ada outlier, independen, konstan (homoskedisitas) dan tidak ada autokorelasi (multikolineariti). ${ }^{11}$

Linearitas diketahui dengan membuat scatter plot antara variabel bebas dengan variabel terikat.Asumsi linearitas terpenuhi apabila scatter plot memberikan kesan linear.Berdasarkan gambar1, maka didapatkan gambaran scatter plot yang menurut asumsi peneliti tidak memberikan kesan yang linear.Hal ini menjadikan syarat pertama 
dan utama untuk diteruskan kepada analisis multivariat regresi linear tidak terpenuhi.

Awal mulanya peneliti mengira linearitas tidak terbentuk karena berasal dari berbagai macam responden sehingga memberi gambaran peak yang sangat bervariasi.Namun setelah dilihat pada masing-masing responden untuk peak $\mathrm{X}$ dan $\mathrm{Y}$ pada gambar3, 4 dan 5ternyata linearitas memang tidak terbentuk.

Hasil pada penelitian ini berbeda dengan penelitian sebelumnya yang dilakukan oleh Andrasko.Pada penelitian Andrasko ${ }^{5}$, sebelumnya dinyatakan bahwa peak $\mathrm{X}$ akan mengalami peningkatan seiring dengan bertambahnya umur bercak darah. Peningkatan peak $\mathrm{X}$ akan tampak nyata pada hari $1 \mathrm{~s} / \mathrm{d} 15$, selanjutnya melewati hari ke 15 grafik peak $\mathrm{X}$ mengalami flattening (pendataran).

Pada penelitian ini, seperti yang terlihat pada gambar2, didapatkan bahwa peak X memiliki gambaran yang tampak seolah-olah menyerupai double peaks.Hasil peak Y pada penelitian ini bila dibandingkan penelitian terdahulu juga memiliki perbedaan. Pada penelitian terdahulu dijelaskan bahwa peak $\mathrm{Y}$ pada hari $1 \mathrm{~s} / \mathrm{d} 2$ penyimpanan akan mengalami peningkatan peak, setelah itu untuk jangka waktu yang lama tidak mengalami perubahan. ${ }^{5}$ Sedangkan pada penelitian ini, peak $\mathrm{Y}$ mengalami peningkatan pada hari $1 \mathrm{~s} / \mathrm{d} 8$, lewat dari hari tersebut terjadi penurunan peak yang cukup drastis. Hasil yang berbeda pada penelitian ini karena adanya perbedaan perlakuan, karena suhu dan kelembaban dibiarkan mengikuti kondisi iklim yang ada di wilayah Jakarta Pusat.Sedangkan pada penelitian Andrasko, ${ }^{5}$ suhu diatur pada kondisi 0p $\mathrm{C}$, 23p C dan 37p C, dengan rentang kelembaban udara berkisar antara $15-65 \%$.

Faktor-faktor yang memungkinkan tidak terjadinya linearitas pada penelitian ini akan ditinjau dari 4 aspek, yakni: kadar $\mathrm{Hb}$ dari tiap-tiap responden, perbedaan rentang waktu pengambilan sampel dengan waktu analisis HPLC, faktor pada alat HPLC, dan terakhir adalah suhu dan kelembaban udara.

Pada aspek kadar hemoglobin ( $\mathrm{Hb})$. Jika memperhatikan kadar $\mathrm{Hb}$ responden, maka terlihat bahwa sebenarnya semua responden tidak memenuhi kriteria inklusi syarat $\mathrm{Hb}$ normal berdasarkan kepustakaan yang ada, yakni untuk lakilaki > 13,5 gr/dl dan perempuan > $12 \mathrm{gr} / \mathrm{dl}$. Pertimbangan tetap diikutsertakannya responden meskipun tidak memenuhi syarat inklusi, karena kadar $\mathrm{Hb}$ normal seseorang dipengaruhi oleh berbagai macam faktor seperti umur, jenis kelamin, adanya kehamilan dan ketinggian tempat tinggal. Rujukan $\mathrm{Hb}$ normal pada penelitian ini mengambil literatur dari luar yang memiliki standar yang berbeda dengan orang Indonesia. Oleh karena itu, beberapa peneliti di Indonesia mengambil jalan tengah bahwa cut off point kriteria anemia adalah kurang dari $10 \mathrm{gr} / \mathrm{dl} .{ }^{12}$ Pada penelitian ini, sebelum darah responden diambil terlebih dahulu dilakukan pengecekan kadar $\mathrm{Hb}$ dengan alat $\mathrm{Hb}$ test serta dilakukan pemeriksaan tanda-tanda gejala umum bagi penderita anemia yakni gambaran pucat pada wajah, dimana gambaran pucat tersebut lebih jelas diamati pada selaput lendir daerah mulut dan kelopak mata. Pemeriksaan tanda-tanda pucat tersebut tidak ditemukan pada semua responden.

Peak X dan Y pada penelitian ini sesungguhnya bukanlah suatu komponen protein. Meskipun penelitian sebelumnya belum dapat diketahui apa sesungguhnya komponen peak $\mathrm{X}$ dan $\mathrm{Y}$ tersebut, namun pembuktian bahwa peak X dan Y bukan merupakan komponen protein telah dilakukan oleh Andrasko ${ }^{5}$, dengan cara melakukan ekstraksi mempergunakan metanol. Metanol tersebut berfungsi untuk mendenaturasi protein.Ternyata hasil peak $\mathrm{X}$ dan Y pada ekstraksi dengan metanol tidak mengalami pelemahan bahkan justru mengalami penguatan.Dengan demikian, dapat dibuktikan bahwa peak $\mathrm{X}$ dan $\mathrm{Y}$ merupakan hasil produk degradasi dari heme dan bukan merupakan komponen protein.

Hemoglobin merupakan suatu bentuk protein yang kompleks yang tersusun oleh senyawa protein globin dan senyawa non-protein yang bernama heme, dan heme sendiri merupakan suatu senyawa lingkar bernama porfirin dan ditengahnya terdapat 1 ion Fe. ${ }^{13}$ Jadi heme adalah perpaduan antara senyawa Fe-Porfirin, sedangkan hemoglobin adalah perpaduan antara globin-heme. Memperhatikan penelitian sebelumnya bahwa kecil kemungkinan peak X maupun Y adalah protein, maka diasumsikan bahwa peak X dan $\mathrm{Y}$ merupakan $\mathrm{Fe}$ atau porfirin. Hal ini bisa dijadikan dasar penelitian lebih lanjut 
untuk melihat apakah terdapat hubungan antara peningkatan peak $\mathrm{X}$ dan $\mathrm{Y}$ seseorang dengan kadar Fe yang dimilikinya untuk dijadikan bukti yang dapat menyatakan bahwa peak $\mathrm{X}$ dan $\mathrm{Y}$ tersebut adalah Fe. Untuk itu perlu dilakukan pemeriksaan kadar Fe dalam tubuh, dimana normalnya seorang laki-laki dewasa mempunyai kandungan besi $50 \mathrm{mg} /$ $\mathrm{KgBB}$, sedangkan pada perempuan dewasa adalah $35 \mathrm{mg} / \mathrm{KgBB} .{ }^{14}$

Aspek lain yang mungkin menyebabkan fluktuatif peak X dan Y pada penelitian ini adalah waktu pengambilan sampel dan analisis sampel tidak dapat dilakukan pada waktu yang sama setiap harinya. Hal ini menjadi keterbatasan peneliti dikarenakan waktu pemakaian laboratorium HPLC untuk penelitian harus disesuaikan dengan jadwal penggunaan laboratorium di Departemen Kimia Fakultas MIPA UI Depok. Sehingga rentang waktu antara pengambilan dengan analisis sampel tidak bisa tepat 24 jam setiap harinya.

Faktor alat HPLC terhadaphasil analisis peak $\mathrm{X}$ dan $\mathrm{Y}$ akan dipengaruhi oleh jenis kolom fase diam, kecepatan alir pada HPLC dan retensi waktu. Jika memperhatikan faktor-faktor tersebut dimana alat sebagai penyebab terjadinya fluktuatif peak $\mathrm{X}$ dan Y, maka hal ini dapat disingkirkan karena setiap sampel mengalami perlakuan yang sama pada saat dianalisis oleh HPLC. Pada penelitian ini, kolom pada fase diam mempergunakan ODS (oktadesil silika atau $\mathrm{C}_{18}$ ) dengan panjang $250 \mathrm{~mm}$ dan diameter internal 4,6 mm, kecepatan alir pada alat diatur di angka $0,5 \mathrm{ml} /$ detik dan sebelum diinjeksikan ke HPLC, sampel terlebih dahulu diekstraksi dengan aquades lalu di sentrifuge pada kecepatan 1000 rpm selama 20 menit.

Perbedaan terjadi pada retensi waktu.Retensi waktu adalah waktu yang dibutuhkan oleh senyawa untuk bergerak dari kolom fase diam menuju detektor. Pada penelitian sebelumnya, rata-rata retensi waktu untuk peak $\mathrm{X}$ adalah 4,9 menit, sedangkan untuk peak Y 9,9 menit. Pada penelitian ini, rata-rata retensi waktu untuk peakX adalah 7,2 menit sedangkan untuk peak $\mathrm{Y}$ adalah 7,5 menit. Perbedaan ini timbul disebabkan oleh perbedaan kecepatan alir dengan penelitian sebelumnya. Pada penelitian sebelumnya kecepatan alir diatur pada 0,8 $\mathrm{ml} /$ detik, sehingga hal ini berdampak pada tekanan yang diberikan.
Aspek terakhir yang dapat mempengaruhi hasil peak X dan Y adalah suhu dan kelembaban udara.Andrasko ${ }^{5}$ menyatakan bahwa kekurangan dari penentuan umur bercak darah dengan mempergunakan metode kimia adalah hasilnya sangat dipengaruhi oleh lingkungan, terutama suhu dan kelembaban udara.Hal ini mungkin yang mendasari penelitian sebelumnya adanya perlakuan terhadap suhu udara dalam meneliti peak yang terdapat pada bercak darah.

Pada penelitian yang dilakukan oleh Inoue ${ }^{15}$ disimpulkan bahwa persamaan regresi linear dapat dihasilkan untuk melihat hubungan peak $\mathrm{X}$ dengan waktu penyimpanan bercak darah.Hanya saja penelitian tersebut masih dilakukan secara in vitro atau adanya perlakuan, yakni bercak darah dipaparkan sinar fluorescent pada suhu ruangan dan $37 \mathrm{p} \mathrm{C}$ dengan waktu pengamatan selama 52 minggu.

Pada penelitian ini, bercak darah pada kain katun dibiarkan terpapar oleh pengaruh lingkungan.Hal ini dilakukan agar hasil yang diperoleh dapat merepresentasikan kondisi riil penemuan bercak darah pada TKP.Pada penelitian ini setidaknya ada 3 hal yang menjadi paparan terhadap bercak darah, yakni suhu udara, kelembaban udara dan paparan sinar matahari langsung. Penelitian ini akan mendeskripsikan pengaruh perubahan suhu dan kelembaban udara dengan perubahan peak X dan Y pada HPLC.

Jika kita amati gambar 2 akan terlihat bahwa gambaran kenaikan dan penurunan peak $\mathrm{X}$ secara fluktuatif pada semua responden menyerupai gambaran double peak, dimana pada hari 9 s/d 11 mengalami penurunan peak X. Bila kita amati gambar 6 yang merupakan grafik perubahan suhu udara, akan terlihat kesamaan pola pada hari ke $9 \mathrm{~s} /$ d 11 dimana pada waktu-waktu tersebut suhu mengalami penurunan yang drastis. Sedangkan untuk kelembaban udaraakan terlihat pola yang hampir sama pada hari $1 \mathrm{~s} / \mathrm{d} 8$. Namun pada hari 9 s/d 11 disaat peak $\mathrm{X}$ mengalami penurunan, kelembaban udara justru mengalami peningkatan.Jadi dengan membandingkan ketiga grafik tersebut, tampak bahwa peak $\mathrm{X}$ terlihat berbanding lurus dengan perubahan suhu udara namun berbanding terbalik dengan perubahan kelembaban udara. 
Perubahan peak Y pada semua responden sesuai gambar2, tergambar bahwa peak $\mathrm{Y}$ pada hari $1 \mathrm{~s} / \mathrm{d} 8$ terjadi peningkatan, namun pada hari ke $9 \mathrm{~s} /$ d 11 terlihat grafik peak Y mengalami penurunan yang sangat drastis. Bila kita amatigambar 6 untuk perubahan suhu kelembaban udara, maka akan terlihat pola yang menarik pada hari $9 \mathrm{~s} / \mathrm{d} 11$. Pada waktu-waktu tersebut peak $\mathrm{Y}$ mengalami penurunan yang sangat drastis, hal yang sama pula terjadi pada grafik perubahan suhu udara, sedangkan pada grafik perubahan kelembaban udara mengalami peningkatan yang drastis. Pola deskripsi peak $\mathrm{Y}$ dengan suhu dan kelembaban udara tidak jauh berbeda dengan pola peak $\mathrm{X}$ dengan suhu dan kelembaban udara.Dimana peak $\mathrm{Y}$ terlihat berbanding lurus dengan perubahan suhu namun berbanding terbalik dengan perubahan kelembaban udara.

Penelitian-penelitian sebelumnya menyatakan bahwa peningkatan peak $\mathrm{X}$ dengan mempergunakan HPLC dapat dijadikan marker untuk penentuan umur bercak darah. Bahkan penelitian Inoue ${ }^{15}$ telah mendapatkan rumus persamaan regresi linear untuk penentuan umur bercak darah manusia yakni In $(1000 . R x)=2,4477+0,0866 . W(r=0,9826, n=$ 144, $\mathrm{p}<0,001$ ), dimana $\mathrm{Rx}$ adalah perubahan rasio peak X dan $\mathrm{W}$ adalah waktu dalam minggu. Namun kesemua penelitian tersebut dilakukan pada suhu dan kelembaban udara yang telah diatur sedemikian rupa. Sehingga kesimpulan pada penelitian ini menyatakan bahwa teknik penentuan umur bercak darah dengan melihat perubahan peak X pada HPLC baru dapat dipergunakan secara pragmatis dengan kondisi riil yang ada di TKP dengan terlebih dahulu melakukan faktor koreksi terhadap perubahan suhu dan kelembaban udara.

\section{KESIMPULAN}

Pada penelitian penentuan umur bercak darah pada kain katun dengan mempergunakan HPLC (High Performance Liquid Chromatography) sesuai dengan lingkungan di wilayah Jakarta Pusat ini, tidak didapatkan linearitas (kesegarisan) untuk memenuhi persyaratan persamaan regresi linear.Hasil Peak X hasil analisis HPLC pada penelitian ini yang berbentuk seperti double peak, memiliki perbedaan dengan penelitian sebelumnya yang berbentuk seperti kurva logaritma.Peak Y pada hasil penelitian ini memiliki kemiripan hasil dengan penelitian sebelumnya, dimana pada hari-hari awal akan mengalami kenaikan peak, kemudian mengalami kecenderungan menurun pada hari-hari berikutnya.

Pada penelitian ini terlihat hubungan antara pola grafik hasil analisis HPLC berupa peak $\mathrm{X}$ dan $\mathrm{Y}$ yang berbanding lurus dengan perubahan suhu udara dan berbanding terbalik dengan perubahan kelembaban udara.Berdasarkan data-data dan hasil analisis pada penelitian ini didapatkan kesimpulan bahwa penentuan umur bercak darah pada kain katun dengan melihat perubahan peak X pada HPLC belum dapat dipergunakan secara pragmatis di TKP.

\section{DAFTAR PUSTAKA}

1. Bremmer RH, De Bruin KG, Van Gemert MJC, Van Leeuwen TG, Aalders MCG. Forensic Quest for Age Determination of Bloodstain. Elsevier, 2011

2. Bauer M, Polzin S, Patzelt D. Quantification of RNA degradation by semiquantitative duplex and competitive RT-PCR: a possible indicator of the age of bloodstain. Forensic Science International 138, 2003. Pg 94-103

3. Anderson S, Howard B, Hobbs GR, Bishop CP. A Methode for determining the age of a bloodstain. Forensic Science International 148, 2005. Pg 37-45

4. Bremmer RH, De Bruin KG, Van Gemert MJC, Van Leeuwen TG, Aalders MCG. Age estimation of blood stain by hemoglobin derivative determination using reflectance spectroscopy. Forensic Science International 206. 2011. Pg 166 $-171$

5. Andrasko J. The estimation of the age of bloodstains by HPLC analysis. Journal Forensic Science 42. 1997. Pg 601-607

6. Fujita et al. Estimation of the age of human bloodstains by electron paramagnetic resonance spectroscopy: Long-term controlled experimenton the effect of environmental factors. Forensic Science International 152. 2005. Pg 39 $-43$ 
7. Rajamannar K. Determination of the age of bloodstains using immunoelectrophoresis. Journal Forensic Science Vol 22 No 1. 1977. Pg 159-164

8. Dahlan MS. Besar Sampel dan Cara Pengambilan Sampel dalam Penelitian Kedokteran dan Kesehatan. Jakarta: Penerbit Salemba Medika, 2010 Hal 99-100

9. McPhee SJ, Papadakis MA, Tierney LM. Current Medical Diagnosis and Treatment. San Fransisco: Mc Graw Hill, 2007

10.Dahlan MS. Statistik untuk Kedokteran dan Kesehatan. Jakarta: Penerbit Salemba Medika, 2011 Hal 1-28

11.Dahlan MS. Analisis Multivariat Regresi Linear. Jakarta: Epidemiologi Indonesia, 2012 Hal 3-13
12.Bakta IM. Pendekatan Terhadap Pasien Anemia dalam: Buku Ajar Ilmu Penyakit Dalam Jilid II Edisi IV. Jakarta: Pusat Penerbit Departemen Ilmu Penyakit Dalam Fakultas Kedokteran Universitas Indonesia, 2006 Hal 632-636

13.Sadikin M. Biokimia Darah. Jakarta: Penerbit Widya Medika, 2002 Hal 12-24

14.Bakta IM, Suega K, Dharmayuda TG. Anemia Defisiensi Besi dalam: Buku Ajar Ilmu Penyakit Dalam Jilid II Edisi IV. Jakarta: Pusat Penerbit Departemen Ilmu Penyakit Dalam Fakultas Kedokteran Universitas Indonesia, 2006 Hal 644

15.Inoue H, Takabe F, Iwasa M, Maeno Y, Seko Y. A new marker for estimation of bloodstain age by high performance liquid chromatography. Forensic Science International 57. 1992. Pg 1727 